\title{
Hutang Luar Negeri Swasta Indonesia: Permasalahan dan Alternatif Penanganannya
}

\author{
Endang Sih Prapti
}

Initially, private foreign debt is an ordinary case happening in various countries. Private institutions try to find foreign debt because of the lack of the internal fund. Both debtors and creditors would get huge economic benefits, as the relation between them can be meant as mutualistic relation. The problem would arise when one or more of three aspects appear; default, rescheduling, or repudiation. The suggested solutions are adjustment program under the MF support, searching for the new debt sources (at moderate rate), finding other financial aid rather than debt.

\section{Pendahuluan}

su Hutang Luar Negeri (HLN) Swasta di Indonesia serius dibicarakan untuk pertama kalinya pada Mei 1991. Sebelumnya HLN selalu dikaitkan dengan HLN Pemerintah. Sejak saat itu dominasi atas Hutang Luar Negeri menurun, di lain pihak peran Swasta dalam HLN semakin meningkat. Isu HL.N Swasta menghangat lagi setelah terjadinya Krisis Moneter Juli 1997, sampai sekarang.

Sebagaimana HLN Swasta pada umumnya, secara teoritis HLN Swasta Indonesia tidak seharusnya bermasalah. Swasta mencari pinjaman luar negeri karena terbatasnya dana yang tersedia di dalam negeri. Di pihak kreditur, HLN mengalir masuk pada debitur Swasta di Indonesia karena dianggap memiliki creditworthiness dan mampu memberikan keuntungan; sedangkan di pihak debitur jika debt management diterapkan dengan baik dan benar, sehingga debitur mampu mempertahankan tingkat solvency bisnisnya serta mampu menghindari "hantu" illiquidity, HLN ini justru akan menguntungkan sektor swasta khususnya dan perekonomian Indonesia umumnya. 
Topik: Hutang Luar Negeri Swasta Indonesia: ...., Endang Sih Prapti

Namun demikian, pada kenyataannya permasalahan telah' terjadi dalam HLN Swasta di Indonesia. Memang permasalahan HLN Swasta di Indonesia baru dalam kategori debt moratotium, tetapi jika tidak segera diatasi tidak mustahil dapat menjadi debt crisis. Permasalahan HLN Swasta di Indonesia terjadi baik dalam pemanfaatan hutang maupun dalam pembayaran kembali hutang. Banyak pihak yang berperan sebagai pemicunya, pihak debitur, pihak kreditur, dan lingkungan bisnis baik domestik maupun internasional.

Di samping itu, HLN Swasta yang seharusnya tidak secara langsung membebani masyarakat, tetapi dalam kasus Indonesia, permasalahan HLN Swasta ternyata telah secara langsung membebani rakyat. Ketidakmampuan Swasta dalam membayar kembali diambil alih oleh otoritas moneter atas tekanan kreditur.

Memang, apabila masalah telah terlanjur terjadi, upaya mencari solusi seringkali menjadi rumit dan alot, karena menyangkut baik faktor penyebab, banyak pihak terbebani, dan banyak elemen pertimbangan. Oleh karenanya, berkaitan dengan HLN Swasta, menghindari masalah tetap merupakan cara terbaik.

\section{Hutang Luar Negeri Swasta: Karakter dan Permasalahan}

\section{Karakter HLN Swasta}

HLN Swasta tidak seharusnya bermasalah. Swasta mencari pinjaman di luar negeri karena terbatasnya dana yang tersedia di dalam negeri. Di pihak kreditur, HLNS mengalir kepada debitur karena debitur dianggap memiliki creditworthiness dan mampu memberikan keuntungan; sedangkan di pihak debitur jika debt management diterapkan dengan baik dan benar, HLNS justru akan memberikan keuntungan serta memberikan kemampuan untuk membayar kembali hutang tersebut beserta bunganya. Hubungan ini akan menghasilkan hubungan simbiosis mutualistik antara kreditur dan debitur yang berkesinambungan, dan semakin meningkat, atau yang disebut self Revolving Debt-Payment Cycle. Lihat Gambar 1.

Agar hubungan HLN Swata menghasilkan Self Revolving Debt - Payment Cycle, diperlukan partisipasi kedua belah pihak, kreditur, dan debitur, dan keadaan lingkungan bisnis yang kondusif.

Dari pihak debitur, kunci keberhasilan terletak pada diperiukan debt management yang baik dalam pemanfaatan hutang yang disertai dengan tingkat forex generation capability (kemampuan menghasilkan devisa) yang tinggi. Kedua elemen keberhasilan tersebut akan membuahkan 3 (tiga) hasil: (1) keuntungan, yang diperlukan untuk sustainability dan ekspansi perusahaan, (2) tingkat solvency (kemampuan mengembalikan hutang) yang tinggi, dan (3) kemampuan menghindari jebakan illiquidity (kelangkaan devisa pembayar pelayanan hutang). Pada gilirannya, keberhasilan ini dapat meningkatkan kemampuan pembayaran kembali hutang sehingga akan meningkatkan creditworthiness debitur dalam pandangan keditur. Jelas terlihat, bahwa tingkat keberhasilan ini banyak ditentukan oleh derajat orientas ekspor (export oriented) dari bisnis debitur.

Dari pihak debitur, diperlukan sikap prudent dalam penilaian creditworthiness dari calon debitur, sikap professional dalam mengantisipasi kebutuhan debitur, dan sikap supportive dalam memahami kesulitan debitur, menyadari bahwa keberhasilankegagalan debitur merupakan bagian dari permasalahan bisnis kreditur sendiri.

Di samping itu, mengingat bisnis, domestik dan internasional, menjadi sangat crucial. Peranan ini seringkali dilihat dari 
kreditur dalam bentuk tingkat country risk dari negara debitur, sedangkan oleh debitur berupa pemahaman akan keadaan lingkungan keuangan internasional yang semakin "terbuka" dan semakin "licin".

\section{Gambar 1. Self Revolving Debt Cycle}

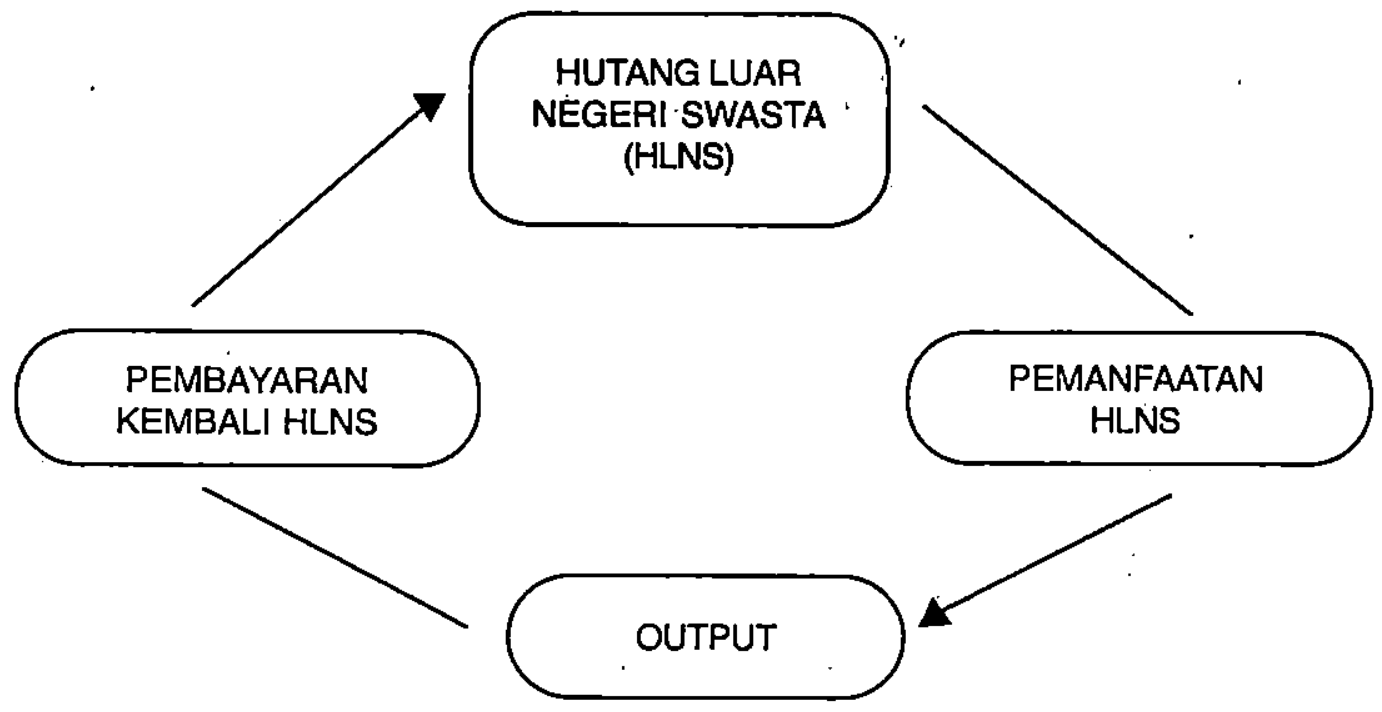

Atas dukungan debitur, kreditur, dan lingkungan bisnis yang kondusif, akan terjadi simbiose mutualisme dalam hubungan HLN Swasta yang dapat menghasilkan Self Revolving Debt - Payment Cycle.

Namun demikian, dalam kenyataannya, utamanya, di negeri negara berkembang (LDCs-Less Developing Countries), yang lebih sering terjadi bukan hubungan HLN Swasta yang simbose mutualistik, melainkan sebaliknya, HLN Swasta yang bermasalah, baik yang masalahnya bersumber pada pihak debitur, pihak kreditur, maupun pada pihak lingkungan bisnis. Permalahan HLN Swasta pada tingkatan yang terberat dapat menimbulkan krisis finansial atau debt crisis.

\section{Permasalahan HLN Swasta}

Dalam mengatasi permasalahan dalam HLN Swasta perlu dilakukan analisis untuk mengetahui akar permasalahannya sehingga dapat dicari solusinya yang tepat.

Pembahasan permasalahan HLN Swasta dapat dikelompokkan ke dalam 4 (empat) kategori, yaitu:

(1) Kadar berat-ringannya masalah

(2) Ekonomi sebagai sumber masalah

(3) Ekonomi Politik sebagai sumber masalah

(4) Lenin's Dictum 


\section{Berat-Ringannya Permasalahan HLN Swasta}

Ada 3 (tiga) macam tingkatan dalam ketegori ini, dari yang teringan sampai terberat tersusum sebagai berikut:

1. Default

2. Moratorium atau Rescheduling

3. Repudiation

Ketiga permasalahan tersebut di atas berpotensi untuk menjadi Debt Crisis. Istilah krisis dalam hal ini memang ini agak menyimpang, karena tidak terjadi global collapse. Yang terjadi adalah runtuhnya struktur kerjasama finansial internasional yang telah terbina selama masa sebelum krisis yang mengakibatkan dunia berada dalam resesi internasional yang dalam. Debt Crisis, yang didefinisikan sebagai pengembangan dan perluasan dari masalah yang ditimbulkan oleh kesulitan dalam pembayaran kembali $H L N$ yang menggunung, yang berakibat mengancam stabilitas sistem finansial internasional, kedudukannya dalam dunia ekonomi politik internasional dianalogikan dengan perang nuklir dalam dunia politik internasional. Debt Crisis seringkali juga diidentikkan dengan krisis pembangunan ekonomi.

\section{Default}

Default adalah ketidakmampuan debitur melakukan Debt Service Payment pada waktu dalam periode pembayaran. Masalah ini termasuk kategori ringan karena dianggap bukan merupakan masalah permanen.

\section{Moratorium}

Moratorium adalah permohonan menunda dan menjadwalkan kembali kewajiban pembayaran kembal hutangnya. Untuk melakukan moratorium, debitur yang bersangkutan harus menempuh 2 (dua) hal: (1) sudah menjalani program adjustment (penyesuaian) di bawah bimbingan IMF, (2) merundingkannya dengan kelompok pihak kreditur, Paris Club untuk HLN Pemerintah atau London Club untuk HLN Swasta. Dalam bersikap London Club akan mengacu pada sikap Paris Club.

Contoh moratorium HLN yang pernah terjadi cukup serius adalah moratorium yang dilakukan oleh Meksiko. Setelah beberapa dekade sebelumnya sistem finansial internasional berlalu dalam ketenangan, Musim Panas 1982, Meksiko mengumumkan Debt Moratorium terhadap Debt Service Paymentnya. Dalam kasus Meksiko ini imbas yang terjadi adalah Debt Crisis.

\section{Repudiation}

Repudiation adalah penolakan atau pengingkaran pembayaran Debt Service Payment. Permasalahan repudation merupakan permasalahan hutang luar negeri yang paling buruk di mata kreditur. Biasanyà jika debitur melakukan repudiation, debitur yang bersangkutan akan menerima sangsi berupa "embargo" pemberian HLN baru dari sindikat pihak kreditur.

\section{Ekonomi sebagai Sumber Permasalahan}

Kegagalan manajemen HLN atau debt mismanagement HLN Swasta di LDCs, ditinjau dari kategori ekonomi. Kegagalan mismanagement HLN Swasta ini dipicu oleh factor eksternal, meliputi: (1) demam spekulatif (speculative fever) yang melanda sektor bisnis di LDCs pada dekade 1990an, (2) ketergantungan berlebihan pada bisnis orientasi ekspor (export oriented). Di samping itu ada satu factor eksternal yaitu ketimpangan, dan (3) ketimpangan bargaining power ekonomi antara negara- 
negara kreditur dan negara-negara debitur, semakin mempertajam kesulitan permasalahan LN Swasta di LDCs.

Pada dekade 1990-an dunia bisnis di LDCs, ditinjau dari kategori eonomi. Kegagalan mismanagement HLN Swasta ini dipicu oleh factor internal dan factor eksternal, meliputi: (1) demam spekulatif (speculative fever) yang melanda sektor bisnis di LDCs pada dekade 1990-an, (2) ketergantungan berlebihan pada bisnis orientasi ekspor (export oriented). Di samping itu ada satu factor eksternal yaitu ketimpangan, dan (3) ketimpangan bargaining power ekonomi antara negaranegara kreditur dan negara-negara debitur, semakin mempertajam kesulitan permasalahan HLN Swasta di LDCs.

Pada dekade 1990-an dunia bisnis di LDCs terkenal wabah demam spekulatif (speculative fever). Masyarakat swasta begitu mudahnya memperoleh HLN sehingga menurunkan kewaspadaannya terhadap resiko usaha. Akibatnya, bisnis yang dibiayai dengan HLN tersebut dilaksanakan dengan sikap profesionalisme yang rapuh, sehingga banyak yang menderita rugi dan menimbulkan masalah pengembalian hutang.

Kesaiahan terlalu menggantungkan diri pada orientasi ekspor merupakan faktor utama kedua terjadinya mismanagement HLN Swasta. Begitu terobsesinya kepada orientasi ekspor, sampai dunia bisnis di LDCs terlena bahwa kekuatan ekspornya diletakkan di atas dasar yang rapuh dan terlena bahwa pasar domestiknya merupakan pasar yang luar biasa besarnya. Kelemahan ini diperparah pasca Krisis Ekonomi-Moneter 1997 oleh adanya "paksaan" untuk "back to nature", kembali menjadi pengekpor barang primer, yang terms of trade dan pasarnya dikuasai negara importir yang merupakan negara kreditur. Sebagai akibatnya, HLN Swasta di negara-negara LDCs (utamanya Asia) masuk ke dalam pusaran jebakan hutang (debt trap), yang dipicu oleh jebakan illiquidity. Terjadilah permasalahan HLN swasta yang mengarah kepada debt crisis, yang berlangsung sampai saat tulisan ini dibuat.

Faktor ketiga, ketimpangan bargaining power ekonomi antara negara-negara kreditur dan negara-negara debitur, semakin mempertajam kesulitan permasalahan HLN Swasta di LDCs menyebabkan semua kunci solusi masalah HLN Swasta berada di tangan kreditur, yang jelas akan mendahulukan kepentingan dibanding kepentingan debitur.

Ketiga faktor ini saling membelit dan menjadikan HLN Swasta di LDCs tidak lagi merupakan sekedar permasalahan kategori ringan atau problema atau pro-lemma (masalah yang masih ada solusinya), tetapi sudah menjurus kepada permasalahan debt crisis yang merupakan suatu dilemma (masalah tanpa solusi).

\section{EKONOMI POLITIK SEBAGAI SUMBER PERMASALAHAN}

Membawa politik dalam pemecahan masalah HLN Swasta dan manajemennya memerlukan 3 cara dalam mana peranan politik mempengaruhi keuangan intemasional, yaitu:

1. Menjelaskan tentang pola manajemen krisis (crisis management), utamanya tentang tindakan yang harus diperbaharui di sisi pemerintah negara kreditor dan Dana Moneter Internasional (IMF)

2. Menjelaskan hubungan rumit antara bank-bank komersial dan pemerintah di negara-negara kreditur, yang akan memberikan bentuk kegiatan-kegiatan pada para pemain utama dalam sistem finansial. 
Topik: Hutang Luar Negeri Swasta Indonesia: ...., Endang Sih Prapti

3. Memainkan peran crucial dalam kalkulasi-kalkulasi yang harus dilakukan oleh pemerintah negaranegara debitur untuk mengadakan program-program adjustment secara drastis dan imbalan tambahan bantuan dalam jumlah terbatas dan penjadwalan kembali uangnya untuk memunculkan insentif bagi debitor. Konsekuensi politik dari adjustment measures ini antara lain berupa kondisi ekonomi yang semakin memburuk, resistensi politis, atau menurunnya legitimasi pemerintah di negara debitur.
Menurut pendekatan ekonomi politik konversi dari permasalahan HLN menjadi debt crisis dapat disebabkan oleh 3 (tiga) hal:

\section{Goncangan Ekonomi Makro (Macroeconomic Shock)}

Macro economic shock merupakan argumentasi konjungtural. Ada pergeseranpergeseran mendadak (mengejutkan) dalam kebijakan ekonomi makro di negara kreditur, yang menyebabkan kesulitan pembayaran HLN kembali, yang cenderung mengarah kepada debt crisis. Penjelasannya cara arrow mechanism adalah sebagai berikut:
Di negara kreditur : $\mathrm{i} \uparrow \rightarrow \mathrm{I} \downarrow \rightarrow \mathrm{Y} \downarrow \rightarrow \mathrm{M} \downarrow$
Di negara debitur : $\quad \mathrm{X} \downarrow \rightarrow \mathrm{Y} \downarrow$ dan DSR $\uparrow \rightarrow$ Debt Crisis

(Catatan: $1=$ tingkat bunga; $I=$ investasi $Y=$ pandangan nasional; $X=$ penerimaan ekspor; $M=$ pembayaran impor; $D S R=$ debt service ratio, rasio pembayaran cicilan pokok plus bunga HLN terhadap penerimaan ekspor).

Argumentasi ini disukai oleh LDCs (debitur) karena menyalahkan DCs (kreditur).

\section{Kegagalan Adjustment (Failure to adjust)}

Argumentasi ini menyalahkan LDCs. Debt crisis disebabkan oleh ketidakcukupan alat kebijakan untuk melakukan adjusment terhadap dampak masalah HLN Swasta.

Menurut argumen ini lingkungan ekonomi tidak dapat menjadi penyebab utama atas menurunnya perekonomian. Pengaruh positif.pertumbuhan ekonomi DCs yang seharusnya menguntungkan LDCs, masih perlu disertai kendali ketat (short lesh) dari IMF; baik dari conditionality nya (yang lazim dikenal dengan Letter of Intent atau Lol) maupun dari renegosiasi antara IMF dan negara debitur.
Asumsi yang mendasari argumentasi failure to adjust adalah bahwa "keterbatasan (limit) dalam pembiayaan relatif tetap sedangkan keterbatan (limit) dalam adjusment relatif fleksibel". Hal ini tergantung pada kemauan kreditur untuk memainkan peranan yang memadai dalam proses pembiayaan. Jika tidak, negara debitur terancam oleh semakin meningkatnya beban HLN Swastanya.

\section{Imperfection in financial market}

Dalam argumen ini, bank tidak dianggap sebagai sistem intermediaries yang efektif melainkan sebagai suatu sistem yang 
mudah terjerumus dalam krisis. Juga, lender of the last resort dilihat sebagai suatu sistem yang memiliki masalah tindakan kolektif dalam sindikat perbankan yang dapat mengancam stabilitas sistem. Efek contagion (menular) dan herd behavior (perilaku ternak-semacam badwagon effect) menghasilkan siklus hutang yang berkisar antara dua ekstrim "panen dan kelaparan" (feast and famine). Akibatnya kepercayaan menjadi meluntur.

Argumen ini lebih menunjuk pada ketidakcukupan, bukan ketidakmampuan regulasi dalam hubungan HLN, sebagai penyebab debt crisis. Ketidakcukupan regulasi yang dimaksud adalah dalam menghadapi resiko dari sovereign lending. resiko yang timbul akibat kebanyakan bank mengalami mypia disaster (malapetaka akibat pandangan yang sempit). Tindakan kreditur mengalihkan untuk mengubah arah dari alokasi dana pinjamannya dari semua berupa alokasi secara mulus ke negaranegara dengan tingkat pertumbuhan ekonomi dan tingkat hasil yang tinggi ke negara-negara dengan asumsi countries never go bankrupt, merupakan ancaman kegagalan pengembalian utang, dan menjadi hambatan menuju tingkat pemberian dan distribusi HLN yang optimal.

Manakala intermediaries finansial swasta telah menjadi santral, dan permasalahan market imperfection (pasti) muncul, maka Pemerintah atau Otoritas Moneter potensial untuk mencampuri pasar dengan 3 tugas politik yang meletakkan batas-batas bagi pelaku swasta dan mempengaruhi perilaku swasta.

Ketiga tugas tersebut adalah:

1. Memastikan adanya stabilitas sistem finansial internasional, menggunakan 2 cara: a. Menjadi lending of the las resort, (menggunakan antara lain rekening 502 dan/atau Rekening 519), artinya Pemerintah dan Otoritas Moneter memiliki kemampuan untuk menyediakan kemauan menambah likuiditas pada resiko yang lebih tinggi dibanding swasta mau melakukan. Peranan negara di sini adalah untuk memelihara kepercayaan kreditur. Yang menggarisbawahi kebutuhan akan lender of the last resort ini adalah kepercayaan bahwa pasar finansial internasional memang bersifat tidak stabil sebagai akibat dari strukturnya (merupakan kegiatan kolektif dan dari sejumlah kreditur), rapuh dalam kepercayaan, dan ancaman contagion.

b. Mengambil tindakan-tindakan yang diperlukan untuk memperkuat kembali kepercayaan dari kreditur luar negeri secara tidak langsung dengan memastikan kemampuan dan kemauan debitur untuk membayar hutang-hutangnya.

2. Tugas politik kedua dari pemerintah adalah melakukan regulasi yang mampu memelihara keamanan dan keberhasilan sistem finansial. Pemerintah dapat juga mengalihkan aliran finansial dari penentuan pasar menjadi untuk kepentingan nasional, seperti pencapaian tujuan kebijakan luar negerinya.

3. Pemerintah negeri debitur bertanggungjawab melakukan adjustment yang diperiukan untuk menjamin kepastian jadwal pengembalian utang dan menjamin kesinambungan aliran masuk modal yang diperlukan untuk pembangunan. 
Topik: Hutang Luar Negeri Swasta Indonesia: ...., Endang Sih Prapti

\section{Lenin's Dictum}

Lenin's Dictum sebagai faktor yang ikut andil dalam memperberat beban pembayaran kembali HLN Swasta dari LDCs, sesungguhnya dapat dimasukkan ke dalam faktor penyebab ekonomi-politik, namun karena keunikannya memerlukan pembahasan tersendiri.

Lenin's Dictum pada dasarnya percaya bahwa cara terefektif untuk menghancurkan suatu perekonomian adalah melalui penghancuran sistem moneternya ("the most effective way to destroy a society is todestroy its currency" - Friedman, 1986, hal. 39).

Pada umumnya Lenin's Dictum dilakukan atas dasar alasan politis, dan seringkali digunakan sebagai "alat serangan" dalam hubungan antara negara yang bersifat independensi, atau sebagai "alat hukuman" dalam tata ekonomi-politik dunia yang timpang (dependensi). Caranya adalah dengan memasok secara besar-besaran mata uang "negara korban" yang digunakan untuk membeli matauang "negara pelaku", sehingga matauang "negara korban" terdeoresiasi secara tajam. Akibat selanjutnya, dapat dipastikan "negara korban" akan mengalami krisis moneter-ekonomi yang parah yang akan menghancurkan perekonomiannya. Keberhasilan "serangan" Lenin's Dictum dipengaruhi oleh ketepatan waktu "serangan", yaitu pada waktu "negara korban" sedang dalam kondisi fundamental ekonomi yang rapuh.

Lenin's Dictum pertama kalinya menjadi perhatian dunia adalah ketika pada awal dekade 1970-an Uni Sovyet dan Iran melepas cadangan emasnya ke pasar untuk menghancurkan nilai USD yang pada saat itu dikaitkan dengan emas (fixed exchange rate system). Usaha tersebut gagal, karena pada saat itu fundamental ekonomi AS cukup kuat. Sebaliknya, hancurnya Uni Sovyet pada awal dekade 1990-an banyak dicurigai sebagai akibat dari penggunaan Lenin's Dictum oleh Nlok Barat dengan "memasok" Robel (matauang Uni Sovyet) secara besar-besaran untuk membeli USD, sehingga kurs Rubel terpuruk. Keberhasilan Lenin's Dictum kali ini karena fundamental ekonomi Uni Sovyet sedang sangat rapuh akibat musim dingin berkepanjangan.

HLN swasta merupakan target antara yang empuk bagi keberhasilan Lenin's Dictum. Hal ini dimungkinkan oleh karakter arbitrage dari hutang luar negeri itu sendiri, dan diperburuk oleh sifat pasar keuangan internasional yang terbuka, licin dan timpang. Dampak terdepresiasinya matauang domestik akan menjadi berlipatganda jika Lenin's Dictum dilakukan tepat pada HLN Swasta jatuh tempo. Akibat selanjutnya dari merosot tajamnya nilai matauang domestik tersebut sudah dapat diduga, "sekali tepuk dua lalat mati", yaitu: (1) beban pembayaran kembali HLN Swasta menjadi tak terbayarkan, (2) sistem moneter domestik collapse. Perekonomian berroller-coastermenuju keterpurukan.

Sikap "negara potensial korban" dalam menghadapi Lenin's Dictum dapat dilakukan antara lain dengan cara:

(1) Defensif, menjaga agar fundamental ekonomi senantiasa kuat.

(2) Defensif, selalu mewaspadai kepemilikan matauangnya oleh negara lain yang berpotensi sebagai "negara penghukum"

(3) Defensif, mengendalikan cara (2) secara ketat ditambah dengan sterilisasi sistem finansial domestik dari pengaruh pasar finansial internasional, yaitu dengan menggunakan sistem kurs tetap (dilakukan secara berhasil oleh Malaysia, 1998-sekarang).

(4). Ofensif, mengancam akan melakukan devaluasi. Dasar pemikirannya adalah daripada negara lain yang me- 
Topik: Hutang Luar Negeri Swasta Indonesia: ...., Endang Sih Prapti

merosotkan nilai matauangnya lebih baik dilakukan sendiri, sehingga kendali masih tetap berada di tangan sendiri. Ancaman ini akan berhasil jika "negara pelaku" takut kehilangan pasar ekspor di "negara potensial korban" jika devaluasi jika didakan (dilakukan secara berhasil oleh RRC, 1998/1999).

Dibandingkan dengan faktor penyebab masalah HLN Swasta yang lain, Lenin's Dictum merupakan penyebab terbutuk. Dapat dilihat, bahwa keempat sikap menghadapi Lenin's Dictum di atas tak ada satu pun yang bersifat curatif, semuanya anticipative. Sekali terjadi Lenin's Dictum yang "sukses" maka akan terjadi siklus yang berlawanan (counter cycle) dari Self Revolving Debt-Payment Cycle di "negara korban".

\section{Alternatif Solusi terhadap Debt Crisis}

Hasil beberapa penelitian menunjukkan bahwa permasalahan HLN Swasta di LDCs lebih disebabkan oleh illiquidity (kekurangan likuiditas) dibanding insolvency assets (kebangkutan karena hutang), di mana penyebab utamanya adalah perlambatan pertumbuhan ekonomi di DCs. Dibutuhkan pertumbuhan ekonomi negara-negara IECD sebesar tumbuh 2,5-3\% untuk menghindarkan debitur dari kegagalan pembayaran kembali HLNnya (miles, 1986, hal 35).

Pendekatan ekonomi politik menawarkan tiga serangkaian alternatif solusi terhadap Debt Crisis, yaitu:

1. Adjusment program dengan dukungan IMF

2. Mencari hutang baru at moderate rate

3. Bantuan uang dari IMF dan lembaga donor bileral dan multilateral.

\section{Hutang Luar Negeri Swasta Indonesia: Profil}

Pada Mei 1991, masyarakat Indonesia dihebohkan oleh munculnya berita tentang besarnya angka DSAR dari HLN Swasta yang cukup signifikan besarnya. Berita ini mengejutkan, utamanya bukan hanya karena angka DSR itu sendiri, melainkan karena sebelumnya memang tidak pernah ada berita serius berkaitan dengan HLN Swasta, sekalnya muncul langsung bermasalah. $^{2}$

Bahwa DSR Indonesia telah melampaui angka "lampau merah" 20, sudah biasa didengar sejak dekade 1980-an. Hanya saja, pada masa itu setiap pembicaraan tentang angka DSR selalu hanya dikaitkan dengan DSR dari HLN Pemerintah, karena telah diketahui bahwa HLN Pemerintah memang besar. Di samping itu, pada masa itu HLN Swasta jumlahnya sangat kecil, tidak signitikan bila dibandingkan dengan besarnya HLN Pemerintah.

Penjelasan logis di balik peristiwa tersebut dikaitkan dengan dampak dari serangkaian kebijakan deregulasi moneter Juni 1983, paket kebijakan deregulasi perbankan Oktober 1988 (dikenal dengan Pakto 88), dan kebajikan uang ketat menaikkan suku bunga - pada Februari 1991 (dikenal dengan Paktri 91).

Dua kebijakan pertama dimaksudkan sebagai penyediaan prasarana yang akan

${ }^{2} Y a n g$ lebih menarik dari isu tersebut adalah munculnya pertanyaan tentang "siapa" yang menyebarkan isu, karena ternyata tindakan Pemerintah dalam merespons isu tersebut (KEPPRES 39/91 pada September 1991, tentang seleksi HLNS) telah mendatangkan keuntungan pada sekelompok orang yan sudah "terlanjur" menerima HLN karena nilainya meningkat oleh kelangkaan 
mampu menjamin kelancaran aliran masuk dana (modal dan hutang) ke dalam negeri, sedangkan kebijakan ketiga menghasilkan daya tarik bagi aliran masuk modal atau hutang, yang kesemuanya ikut andil alam membengkakkan HL.N Swasta.

\section{Perbandingan HLN Swasta dan HLN Pemerintah}

Dari data yang tertulis dalam Tabel 1 dapat dilihat bahwa memang benar Hutang Luar Negeri Swasta telah meningkat secara signifikan. Dalam Tabel 1 tersebut dapat diamati tiga macam perbandingan antara HLN Swasta Pemerintah, meliputi (1) perbandingan angka, (2) perbandingan DSR, dan (3) perbandingan pembayaran bunga, dari tahun 1993 sampai tahun 1999.

Tabel 1

Perbandingan Hutang, DSR, dan Pembayaran Bunga antara Swasta dan Pemerintah, 1993/94 - 1999

\begin{tabular}{|c|c|c|c|c|c|c|c|c|c|c|c|c|c|c|c|}
\hline & \multicolumn{5}{|c|}{ Hutang (futa dollar AS) } & \multicolumn{5}{|c|}{ DSR (\%) } & \multicolumn{5}{|c|}{ Pombayaran Bunga (futa dollar AS) } \\
\hline & $\mathbf{s}$ & $\mathbf{g}$ & $\mathbf{P}$ & $\mathbf{g}$ & SP & $\mathbf{s}$ & $\mathbf{g}$ & P - & 9 & Sp & $\mathbf{s}$ & $\mathbf{g}$ & $\mathbf{P}$ & $\mathbf{g}$ & SP \\
\hline $1996 / 1994$ & 23000 & 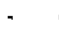 & 60219 & - & 0.4 & 112 & - & 20.6 & - & 0.5 & 1273 & - & 3117 & - & 0.4 \\
\hline $1994 / 1995$ & 33700 & 46.0 & 67578 & 122 & 0.5 & 13.4 & 19.6 & 192 & -6.8 & 0.7 & 2130 & 67.3 & 3421 & 9.8 & 0.6 \\
\hline 199511996 & 55443 & 645 & ๓512 & -6.0 & 0.9 & 14.8 & 10.4 & 17.9 & -6.8 & 0.8 & 2816 & 302 & 3450 & 0.8 & 0.8 \\
\hline $1996 / 1997$ & 71163 & 28.4 & 56281 & -11.4 & 13 & 162 & 9.5 & 18 & 0.6 & 0.9 & 3238 & 15.0 & 3047 & -11.7 & 1.1 \\
\hline $1997 / 1938$ & 80017 & 12.4 & 50001 & 3.1 & 1.4 & 39.4 & 1432 & 11.4 & -36.7 & 3.5 & 4485 & 385 & 2712 & -11.0 & 1.7 \\
\hline 1998 & 79419 & -0.7 & 71468 & 232 & 1.1 & 46.4 & 178 & 11.5 & 0.9 & 4.0 & 5714 & 27.4 & 2053 & 8.9 & 19 \\
\hline 1999 & 67372 & -15.2 & 80725 & 13.0 & 0.8 & 45.9 & -1.1 & 112 & -2.6 & 4.1 & 5745 & 0.5 & 3522 & 193 & 1.6 \\
\hline
\end{tabular}

Keterangan: $\mathbf{S}=$ Swasta; $\quad \mathbf{P}=$ Pemerintah; $\quad \mathbf{g}=$ pertumbuhan (\%) Sumber. IMF 
Topik: Hutang Luar Negeri Șwasta Indonesia: ...., Endang Sih Prapti

Tabel 2

Perbandingan Lalu Lintas Modal Swasta dan Pemerintah, 1981-1986 dan 1991-1996 (juta dollar AS)

\begin{tabular}{|r|r|r|l|r|l|}
\hline & Swasta & $\mathrm{g}$ & Pemerintah & $\mathrm{g}$ & $\mathrm{SP}$ \\
\hline 1981 & 148 & & 1963 & & 0.1 \\
1982 & 1639 & 1007.4 & 4117 & 109.7 & 0.4 \\
1983 & 1826 & 11.4 & 4776 & 16.0 & 0.4 \\
1984 & 700 & -61.7 & 2865 & -40.0 & 0.2 \\
1985 & 68 & -90.3 & 1739 & -39.3 & 0.0 \\
1986 & 1291 & 1291 & 3074 & 76.8 & 0.4 \\
\hline \multicolumn{7}{|c|}{} & & & \\
\hline 1991 & 4410 & $\left.241.6^{\circ}\right)$ & 5638 & $83.4{ }^{\circ}$ & 0.8 \\
1992 & 5359 & 21.5 & 5820 & 3.2 & 0.9 \\
1993 & 5219 & -2.6 & 6005 & 3.2 & 0.9 \\
1994 & 3701 & -29.1 & 5697 & -5.1 & 0.6 \\
1995 & 10253 & 177.0 & 5785 & 1.5 & 1.8 \\
1996 & 10942 & 6.7 & 5626 & -2.7 & 1.9 \\
\hline
\end{tabular}

Keterangan: $g=$ pertumbuhan/thn (5)

$S / P=$ Swasta $/$ Pemerintah

') pertumbuhan 1986 - 1991

Sumber: BPS dan Nota Keuangan

Tabel 3

Hutang Jangka Menengah dan Panjang dari Swasta 1993/94-1999 (Akhir Periode dalam juta dollar AS)

\begin{tabular}{|c|c|c|c|r|r|r|r|r|}
\hline & \multicolumn{2}{|c|}{ Bank } & \multicolumn{2}{c|}{ Nonbank } & \multicolumn{2}{c|}{$\begin{array}{c}\text { Domestik securitles } \\
\text { owed by nonresident }\end{array}$} & \multicolumn{2}{c|}{ Bank } \\
\cline { 2 - 9 } & Nllal & $\begin{array}{c}\text { Share } \\
(\%)\end{array}$ & NIlal & $\begin{array}{c}\text { Share } \\
(\%)\end{array}$ & Nllal & $\begin{array}{c}\text { Share } \\
(\%)\end{array}$ & Nilal & $\begin{array}{c}\text { Share } \\
(\%)\end{array}$ \\
\hline $1993 / 94$ & 8208 & 35.56 & 14873 & 64.44 & 0 & 0.00 & 23080 & 100 \\
$1995 / 5$ & 9017 & 26.76 & 24683 & 73.24 & 0 & 0.00 & 33700 & 100 \\
$1995 / 6$ & 8931 & 16.11 & 34012 & 61.35 & 12500 & 22.55 & 55443 & 100 \\
$1996 / 7$ & 9622 & 13.52 & 47239 & 66.38 & 14302 & 20.10 & 71163 & 100 \\
$1997 / 8$ & 12826 & 16.03 & 60760 & 75.93 & 6431 & 8.04 & 80017 & 100 \\
1998 & 10769 & 13.56 & 63362 & 79.78 & 5288 & 6.66 & 79419 & 100 \\
1999 & 10836 & 16.08 & 53238 & 79.02 & 3298 & 4.90 & 67372 & 100 \\
\hline
\end{tabular}

Sumber: IMF 


\section{Daftar Pustaka}

Baldwin, Robert E., and J. David Richardson, International Trade and Finance: Readings, $3^{\text {rd }}$ ed., Little Brown Company, Boston, 1986.

Batra, Ravi, The Great Depresion of 1990, Simon and Schuster, New York, 1997

Caves, Richard E, and Ronald W. Jones, World Trade and Payments: an introduction, $4^{\text {th }}$ ed., Little Brown Company, Boston, 1985.

Hogendorn, Jan S., and Wilson B. Brown, The New International Economics, Addison Wesley, Massachusets, 1979.

Jüttner, D. Johannes, International Finance and Global Investment, $3^{\text {rd }}$ ed., Longman, Sydney, 1995

Krugman, Paul R., and Maurice Obstfeld, International Economics: Theory and Policy, $4^{\text {th }}$ ed., Addison Wesley Longman, Singapore, 1997.
Payer, Cheryl, The Debt Trap: the IMF and the third world, Monthly Review Press, New York, 1974.

Rivera-Batiz, Fransisco L., and Luis A. Rivera-Batiz, International Finance and Open Economy Macroeconomics, $2^{\text {ind }}$ ed., Macmillan Publishing, New York, 1994

Smith, Adam, The Wealth of Nations, Modern Library, New York, 1937.

Kahler, Miles, The Politics of International Debt, Cornell University, lthaca, 1986

Friedman, Milton, Capitalism and Freedom, The University of Chicago, Chicago, 1982.

Widardjono, Agus, Analisis Constant Market Share Terhadap Ekspor Barang Manufaktur Padat Karya Indonesia Tahun 1975-1978, Skripsi (tidak dipublikasikan). Fakultas Ekonomi Universitas Gadjah Mada, Yogyakarta, 1991. 